\title{
PENINGKATAN PEMBELAJARAN MODEL JIGSAW PADA MATERI LUAS PERMUKAAN BANGUN RUANG SISI DATAR
}

\author{
(IMPROVING JIGSAW LEARNING MODEL \\ ON MATERIAL SURFACE AREA OF \\ THREE-DIMENSIONAL SHAPE)
}

\author{
Luluk Setiyowati ${ }^{1}$ \\ SMA Negeri 2 Kota Mojokerto, luluksetiyowati73@gmail.com
}

\begin{abstract}
Abstrak. Pada pembelajaran menghitung luas permukaan bangun ruang sisi datar yang meliputi kubus, balok, prisma dan limas salah satu materi yang sulit dan hasil ulangan harian nilainya rendah. Hal ini dikarenakan pembelajaran masih berpusat pada guru dimana siswa hanya mendengar, mencatat, serta tidak terlibat aktif dalam pembelajaran yang menggunakan metode konvensional. Penggunaan model Jigsaw ini ternyata dapat meningkatkan pembelajaran materi menghitung luas permukaan kubus, balok, prisma, dan limas dengan data sebagai berikut: persentase hasil observasi aktifitas siswa dalam proses belajar mengajar rata-ratanya $84,17 \%$, persentase hasil observasi aktivitas guru dalam mengajar rata-ratanya $84,09 \%$, rata-rata tes setelah pembelajaran 91,57 dan rata-rata ulangan harian 89,87 dengan persentase siswa yang tuntas $97,22 \%$.
\end{abstract}

Kata kunci : Jigsaw, luas permukaan, bangun ruang sisi datar

\begin{abstract}
In learning to calculate the surface area to three-dimensional shape includes cubes, cuboids, prisms and pyramid, one of the difficult material and the daily test results are low. This is because learning is still teacher-centered where students only listen, take notes, and not active in learning process on conventional methods. The use of the Jigsaw models turns out to be able to improve material learning by calculating the surface area of cubes, cuboids, prisms, and pyramid with the following data: the percentage of the results of the observation of student activities in the teaching and learning process averaged $84.17 \%$, the percentage of the results of the observation of teacher activities in teaching averaged $84.09 \%$, the average test after learning 91.57 and the average daily test 89.87 the percentage of students who completed $97.22 \%$.
\end{abstract}

Keywords: Jigsaw, surface area, three-dimensional shape 


\section{PENDAHULUAN}

Pada pembelajaran menghitung luas permukaan kubus, balok, prisma dan limas salah satu materi yang sulit dan hasil ulangan harian nilainya rendah. Hal ini berdasarkan pengalaman mengajar tahun sebelumnya nilai ulangan pada materi tersebut tidak tuntas secara klasikal. Pembelajaran masih berpusat pada guru dimana siswa hanya mendengar, mencatat, serta tidak terlibat aktif dalam pembelajaran. Hal ini mengakibatkan siswa hanya menghafal konsep tapi tidak bisa mengembangkannya.

Pembelajaran mengenai materi Geometri sering dianggap sebagai suatu kegiatan yang membosankan, kurang menantang, dan tidak bermakna. Akibatnya banyak kritikan yang ditujukan kepada guru diantaranya adalah rendahnya nilai ulangan harian dan kurangnya variasi guru dalam pembelajaran. Agar pembelajaran Matematika pada materi menghitung luas permukaan kubus, balok, prisma dan limas menjadi pembelajaran yang aktif, kreatif, efektif, dan menyenangkan, maka salah satu cara yang cukup efektif adalah melalui penerapan model pembelajaran Jigsaw.

Model Jigsaw dikembangkan dan diuji coba oleh Elliot Aronson dan teman - teman di Universitas Texas. Di dalam model Jigsaw, setiap anggota tim bertanggung jawab untuk menentukan materi pembelajaran yang ditugaskan kepadanya, kemudian mengajarkan materi tersebut kepada teman sekelompoknya yang lain (Ibrahin, M. dkk, 2000 : 21-22). Menurut Suprijono, langkah - langkah Jigsaw adalah 1) Guru membagi kelas menjadi kelompok sesuai dengan jumlah materi yang dipelajari, kelompok ini disebut kelompok ahli; 2) Guru memberi materi tekstual yang berbeda sesuai dengan materi yang dipelajari; 3) Guru meminta siswa dalam satu kelompok ahli mendiskusikan atau mempelajari materi tekstual yang diterima; 4) Setelah selesai mendiskusikan atau mempelajari materi tekstual, guru membentuk kelompok asal dimana dalam anggota kelompok tersebut terdapat semua kelompok ahli. Tiap kelompok ahli mengajar teman kelompok lain secara bergantian; 5) Tiap tim ahli mempresentasikan hasil diskusi; 6) Penarikan kesimpulan; dan 7) Guru memberikan evaluasi (2009 : 90).

Oleh karena itu perlu diadakan Penelitian Tindakan Kelas (PTK) untuk

membuktikan bahwa penerapan pembelajaran model Jigsaw dapat meningkatkan pembelajaran menghitung luas permukaan kubus, balok, prisma dan limas mata pelajaran Matematika. Tujuan penelitian adalah untuk meningkatkan pembelajaran menghitung luas permukaan kubus, balok, prisma dan limas mata pelajaran Matematika dengan model Jigsaw. Penelitian ini hanya meneliti khusus tentang materi menghitung luas permukaan kubus, balok, prisma dan limas mata pelajaran Matematika pada siswa kelas X semester genap tahun pelajaran 2016/2018 di SMA Negeri 2 Kota Mojokerto. 


\section{METODE}

Metode penelitian dalam PTK ini adalah menerapkan penelitian bersiklus yang memuat langkah-langkah: perencanaan, pelaksanaan, observasi, dan refleksi tiap siklusnya. Penelitian dilakukan di SMA Negeri 2 Kota Mojokerto. Subjek penelitian adalah siswa - siswi kelas X sebanyak 32 anak, terdiri dari 10 siswa laki-laki dan 22 siswa perempuan. Instrumen penelitian yang digunakan adalah tugas kelompok, tes setelah pembelajaran, ulangan harian, observasi siswa dan guru, serta angket.

Dalam PTK ini, peneliti menggunakan teknik analisis data kualitatif. Hal ini berdasarkan pendapat Kunandar (2008:101) analisis data kualitatif yang salah satu teknik analisis interaktif yang terdiri atas tiga komponen kegiatan yang saling terkait satu sama lain: reduksi data, beberan data, dan penarikan kesimpulan. Pengujian keabsahan data dapat dilakukan dengan cara trianggulasi data. Kegiatan trianggulasi ini dilakukan dengan jalan melihat hasil hasil tes setelah pembelajaran dan hasil ulangan materi menghitung luas permukaan kubus, balok, prisma dan limas. Kedua data itu dibandingkan dengan hasil observasi peneliti di kelas saat pelaksanaan pembelajaran.

Kriteria keberhasilan dalam PTK ini berhasil apabila memenuhi beberapa syarat, yaitu 1) rata-rata prosentase aktifitas siswa dalam pembelajaran minimal $75 \%$ dan 2) tingkat ketuntasan ulangan harian siswa mencapai 85\% dengan nilai minimal sama dengan KKM yaitu 70.

\section{HASIL DAN PEMBAHASAN}

\section{Hasil Penelitian}

\section{a. Siklus ke-1}

Pada tahap perencanaan PTK pada siklus pertama ini dilaksanakan satu kali tatap muka. Tujuan pembelajaran pada siklus pertama adalah setelah pembelajaran, siswa dapat: 1) Menggunakan rumus untuk menghitung luas permukaan kubus; 2) Menggunakan rumus untuk menghitung luas permukaan balok; 3) Menggunakan rumus untuk menghitung luas permukaan prisma; dan 4) Menggunakan rumus untuk menghitung luas permukaan limas. Evaluasi pembelajaran meliputi evaluasi proses dan evaluasi hasil. Evaluasi proses berupa kegiatan belajar mengajar antara guru-siswa. Evaluasi itu berupa pengamatan terhadap aktivitas siswa dalam kegiatan pembelajaran menghitung luas permukaan kubus, balok, prisma, dan limas dengan menggunakan model Jigsaw. Evaluasi hasil belajar berupa hasil ulangan selesai melaksanakan proses pembelajaran. 
Kegiatan penelitian pada tahap pelaksanaan pada siklus 1 dilaksanakan satu kali pertemuan. Pada kegiatan awal adalah 1) Guru mengabsen siswa; 2) Guru menulis judul dan tujuan pembelajaran; 3) Guru memberikan pertanyaan pada siswa sebagai prasyarat yaitu rumus luas bangun datar (segitiga, persegi, persegi panjang, dll.); dan 4) Memberikan motivasi. Kegiatan inti adalah 1) Membagi 4 kelompok ahli secara heterogen sesuai dengan materinya masing - masing tiap kelompok terdiri-dari 8 anak. Selanjutnya guru membagikan materi yang berbeda kepada masing-masing kelompok ahli untuk mendiskusikan materi mereka dan setiap kelompok bertanggung jawab mempelajari materi tekstual yang diterimanya dari guru; 2) Selesai berdiskusi dalam kelompok ahli, guru membentuk kelompok asal sebanyak 6 kelompok masing-masing sebanyak 6 anak dan tugas masing-masing kelompok asal adalah bergantian menjelaskan materi yang mereka kuasai kepada anggota dalam satu kelompok yang berasal dari kelompok ahli lainnya; dan 3) Guru menyuruh siswa untuk kembali pada kelompok ahli dan mendiskusikan lagi materinya, kemudian dilanjutkan mempresentasikan hasil diskusi. Kegiatan akhir adalah 1) Bersama siswa merangkum hasil kegiatan pembelajaran; 2) Memberi penghargaan kepada kelompok yang bagus cara kerjanya; dan 3) Memberi evaluasi.

Selama pelaksanaan PTK, peneliti bersama dengan kolaborator melakukan pengamatan. Pengamatan guru : 1) Rata-rata tes setelah pembelajaran 52,64; 2) Prosentase siswa yang tuntas pada ulangan harian yang nilainya minimal sama dengan KKM (70) sebanyak 36,11\% dengan rata-ratanya 57,36; 3) Kemampuan siswa menghitung luas permukaan balok, prisma, dan limas masih kurang; dan 4) Rata-rata respon siswa terhadap pembelajaran $86 \%$. Pengamatan kolaborator: 1) Pemberian motivasi sudah baik sehingga anak antusias dalam pembelajaran; 2) Tujuan pembelajaran belum mengena; 3) Pemberian materi prasyarat kurang sehingga siswa belum bisa mengerjakan tugas atau evaluasi akhir; 4) Penguasaan kelas dan pengarahan anak untuk berdiskusi baik; 5) Kemampuan siswa melakukan presentasi sudah baik; 6) Pelaksanaan diskusi pada kelompok asal belum efektif; 7) Pemberian bimbingan dalam mengerjakan tugas kurang; 8) Pemberian evaluasi setelah pembelajaran sudah sesuai dengan rencana; 9) Pemberian penghargaan sehingga siswa semangat mengikuti pelajaran; 10) Kegiatan menyimpulkan materi terlalu cepat; 11) Rata-rata prosentase perolehan skor aktivitas siswa dalam PBM 63,47\%, dan 12) Rata-rata prosentase hasil observasi aktivitas guru dalam mengajar rata-ratanya $63,64 \%$.

Pada tahap refleksi, ditemukan masalah-masalah beserta alternatif pemecahan masalah untuk dilaksanakan pada siklus berikutnya adalah 
1) Pelaksanaan diskusi pada kelompok asal belum efektif. Alternatif pemecahannya: penyederhanaan kelompok dari masing-masing kelompok asal 6 siswa menjadi 4 siswa; 2) Masih ada kelompok ahli yang belum bisa menyelesaikan tugasnya sesuai dengan waktu yang ditentukan. Alternatif pemecahannya: memberikan bimbingan secara intensif pada kelompok yang mengalami kesulitan; 3) Kemampuan siswa menghitung luas permukaan balok, prisma, dan limas masih kurang. Alternatif pemecahannya: membuat perangkat pembelajaran dengan metode tipe Jigsaw yang lebih baik lagi; 4) Prosentase ketuntasan siswa secara klasikal pada ulangan harian kurang dari $85 \%$. Alternatif pemecahannya: membuat perangkat pembelajaran dengan metode tipe Jigsaw yang lebih baik lagi.

\section{b. Siklus ke-2}

Pada tahap perencanaan PTK pada siklus kedua ini dilaksanakan satu kali tatap muka. Tujuan pembelajaran pada siklus kedua adalah setelah dilaksanakan pembelajaran, siswa dapat: 1) Menghitung luas permukaan kubus melalui media kubus yang ditunjukan kepadanya sesuai dengan ukuran dengan baik dan benar; 2) Menghitung luas permukaan balok melalui media balok yang ditunjukan kepadanya sesuai dengan ukuran dengan baik dan benar; 3) Menghitung luas permukaan prisma melalui media prisma segitiga siku-siku yang ditunjukan kepadanya sesuai dengan ukuran dengan baik dan benar; dan 4) Menghitung luas permukaan limas melalui media limas dengan alas persegi yang ditunjukan kepadanya sesuai dengan ukuran dengan baik dan benar. Evaluasi pembelajaran meliputi evaluasi proses dan evaluasi hasil. Evaluasi proses berupa kegiatan belajar mengajar antara guru dan siswa. Evaluasi itu berupa pengamatan terhadap aktivitas siswa dalam kegiatan pembelajaran menghitung luas permukaan kubus, balok, prisma, dan limas dengan menggunakan model Jigsaw. Evaluasi hasil belajar berupa hasil ulangan selesai melaksanakan proses pembelajaran.

Pada tahap pelaksanaan, kegiatan penelitian ini dilaksanakan satu kali pertemuan. Pada kegiatan awal adalah 1) Guru mengabsen siswa; 2) Guru menulis judul dan tujuan pembelajaran; 3) Guru memberikan pertanyaan pada siswa sebagai prasyarat yaitu menanyakan luas bangun datar (segitiga, persegi, persegi panjang, dll.) dan menanyakan unsurunsur kubus, balok, prisma, dan limas; dan 4) Memberikan motivasi yaitu penerapan mencari luas permukaan kubus, balok, prisma, dan limas dalam kehidupan sehari-hari. Kegiatan inti adalah 1) Guru membagi menjadi 4 kelompok ahli secara heterogen sesuai dengan materinya masing-masing tiap kelompok terdiri dari 8 anak. Selanjutnya guru membagikan materi yang berbeda kepada masing-masing kelompok ahli untuk mendiskusikan materi mereka dan setiap kelompok 
bertanggung jawab mempelajari materi tekstual yang diterimanya dari guru. Selain itu masing-masing siswa diberi lembar kerja yang sama sesuai dengan kelompok ahlinya. Lembar tugas untuk siswa adalah mencari proses penemuan rumusan sesuai dengan materi tekstualnya dan menghitung luas permukaan sesuai dengan materi tekstual melalui media yang dibuat siswa; 2) Selesai berdiskusi dalam kelompok ahli, guru membentuk kelompok asal sebanyak 8 kelompok masing-masing sebanyak 4 anak dan tugas masing-masing kelompok asal adalah bergantian menjelaskan materi yang mereka kuasai kepada anggota dalam satu kelompok yang berasal dari kelompok ahli lainnya; 3) Setelah itu guru menyuruh siswa untuk kembali pada kelompok ahli dan mendiskusikan lagi materinya, kemudian dilanjutkan mempresentasikan hasil diskusi. Kegiatan akhir adalah 1) Merangkum hasil kegiatan pembelajaran; 2) memberi penghargaan kepada kelompok yang bagus cara kerjanya; 3) memberi evaluasi; dan 4) Menanggapi jawaban siswa hasil mengerjakan evaluasi untuk mengoreksi kekurangan-kekurangan dalam mengerjakan soal.

Selama pelaksanaan PTK, peneliti bersama dengan kolaborator melakukan pengamatan. Pengamatan guru: 1) Rata-rata tes setelah pembelajaran 68,47 ; 2) Prosentase siswa yang tuntas pada ulangan harian yang nilainya minimal sama dengan KKM (70) sebanyak 80,56\% dengan rata-ratanya 83,63 ; 3) Kemampuan siswa menghitung luas permukaan limas masih kurang; dan 4) Rata-rata respon siswa terhadap pembelajaran 86,52\%. Pengamatan kolaborator: 1) Baik dalam penyampaian tujuan pembelajaran; 2) Baik dalam menyampaikan materi prasyarat; 3) Pemberian motivasi baik sehingga siswa antusias dalam pembelajaran; 4) Dalam pembagian kelompok sampai jalannya pelajaran sudah efektif; 5) Guru dalam mengarahkan siswa menemukan jawaban sudah bagus; 6). Masih ada siswa dalam kelompok yang kerja samanya kurang; 7) Proses penyimpulan materi baik sehingga siswa lebih paham; 8) Pemberian evaluasi setelah pembelajaran baik; 9) Menananggapi jawaban siswa sudah baik; 10) Baik dalam memberikan penghargaan kepada kelompok terbaik; 11) Rata - rata prosentase perolehan skor aktivitas siswa dalam PBM 75,97\%; dan 12) Rata - rata prosentase hasil observasi aktivitas guru dalam mengajar rata - ratanya $72,73 \%$.

Pada tahap refleksi ditemukan masalah-masalah beserta alternatif pemecahan masalah untuk dilaksanakan pada siklus berikutnya adalah 1) Masih ada siswa dalam kelompok yang kerja samanya kurang. Alternatif pemecahannya: pemberian bimbingan untuk mendorong siswa lebih meningkatkan kerja sama dalam satu kelompok; 2) Kemampuan siswa menghitung luas permukaan limas masih kurang. Alternatif 
pemecahannya: membuat perangkat pembelajaran dengan model Jigsaw yang lebih baik lagi; dan 3) Prosentase ketuntasan siswa secara klasikal pada ulangan harian kurang dari $85 \%$. Alternatif pemecahannya: membuat perangkat pembelajaran dengan metode tipe Jigsaw yang lebih baik lagi.

\section{c. Siklus ke-3}

Tahap perencanaan pada PTK pada siklus ketiga ini dilaksanakan satu kali tatap muka. Tujuan pembelajaran pada siklus ketiga adalah setelah pembelajaran, siswa dapat : 1) Menghitung luas permukaan kubus melalui media kubus yang ditunjukan kepadanya sesuai dengan ukuran dengan baik dan benar; 2) Menghitung luas permukaan balok melalui media balok yang ditunjukan kepadanya sesuai dengan ukuran dengan baik dan benar; 3) Menghitung luas permukaan prisma melalui media prisma segitiga siku-siku yang ditunjukan kepadanya sesuai dengan ukuran dengan baik dan benar; 4) Menghitung luas permukaan limas melalui media limas dengan alas persegi yang ditunjukan kepadanya sesuai dengan ukuran dengan baik dan benar; dan 5) Menghitung salah satu panjang sisi jika diberikan soal diketahui luas permukaan bangun ruang dan panjang sisi yang lainnya dengan baik dan benar. Evaluasi pembelajaran meliputi evaluasi proses dan evaluasi hasil. Evaluasi proses berupa kegiatan belajar mengajar antara guru dan siswa. Evaluasi itu berupa pengamatan terhadap aktivitas siswa dalam kegiatan pembelajaran menghitung luas permukaan kubus, balok, prisma, dan limas dengan menggunakan model Jigsaw. Evaluasi hasil belajar berupa hasil ulangan selesai melaksanakan proses pembelajaran.

Kegiatan penelitian ini dilaksanakan satu kali pertemuan. Pada kegiatan awal adalah 1) Guru mengabsen siswa; 2) Guru menulis judul dan tujuan pembelajaran; 3) Guru memberikan pertanyaan pada siswa sebagai prasyarat yaitu menanyakan luas bangun datar (segitiga, persegi, persegi panjang, dll.), menanyakan keliling bangun datar (segitiga, persegi, persegi panjang, dll.), dan menanyakan unsur-unsur kubus, balok, prisma, dan limas; dan 4) Memberikan motivasi yaitu yaitu penerapan mencari luas permukaan kubus, balok, prisma, dan limas dalam kehidupan sehari-hari dan menjelaskan pentingnya materi. Kegiatan inti adalah 1) Guru membagi menjadi 4 kelompok ahli secara heterogen sesuai dengan materinya masing - masing tiap kelompok terdiri dari 8 anak. Selanjutnya guru membagikan materi yang berbeda kepada masing- masing kelompok ahli untuk mendiskusikan materi mereka dan setiap kelompok bertanggung jawab mempelajari materi tekstual yang diterimanya dari guru. Selain itu masing-masing siswa diberi lembar kerja yang sama sesuai dengan kelompok ahlinya. Lembar tugas untuk siswa adalah mencari proses penemuan rumusan sesuai 
dengan materi tekstualnya, menghitung luas permukaan sesuai dengan materi tekstual melalui media yang dibuat siswa, dan menghitung salah satu panjang sisi jika diberikan soal diketahui luas permukaan bangun ruang dan panjang sisi yang lainnya. Guru memberikan bimbingan secara intensif pada masing-masing kelompok ahli yang mengalami kesulitan dan memberikan dorongan untuk bekerja sama dalam satu kelompok ahli; 2) Selesai berdiskusi dalam kelompok ahli, guru membentuk kelompok asal sebanyak 8 kelompok masing-masing sebanyak 4 anak dan tugas masing-masing kelompok asal adalah bergantian menjelaskan materi yang mereka kuasai kepada anggota dalam satu kelompok yang berasal dari kelompok ahli lainnya; 3) Setelah itu guru menyuruh siswa untuk kembali pada kelompok ahli dan mendiskusikan lagi materinya, kemudian dilanjutkan mempresentasikan hasil diskusi; dan 4) Selesai melaksanakan presentasi guru mengadakan tanya jawab untuk mengetahui sejauh mana siswa menguasai materi. Kegiatan akhir adalah 1) Guru dan siswa merangkum/menyimpulkan hasil kegiatan pembelajaran menghitung luas permukaan kubus, balok, prisma, dan limas yaitu dengan cara menjumlahkan semua luas sisinya kemudian disusun dalam bentuk rumusan; 2) Guru memberikan penghargaan dengan memberi hadiah pada kelompok yang bagus cara kerjanya; 3) Guru memberikan evaluasi; dan 4) Menanggapi jawaban siswa hasil mengerjakan evaluasi untuk mengoreksi kekurangankekurangan dalam mengerjakan soal sehingga siswa dapat memahami materi.

Selama pelaksanaan PTK siklus 3 ini, peneliti bersama dengan kolaborator melakukan pengamatan. Pengamatan guru: 1) Rata-rata tes setelah pembelajaran 91,57; 2) Prosentase siswa yang tuntas pada ulangan harian yang nilainya minimal sama dengan KKM (70) sebanyak 97,22\% dengan rata-ratanya 89,87; dan 3) Rata-rata respon siswa terhadap pembelajaran 88,14\%. Pengamatan kolaborator: 1) Baik dalam penyampaian tujuan pembelajaran; 2) Baik dalam menyampaikan materi prasyarat; 3) Pemberian motivasi baik sehingga siswa antusias dalam pembelajaran; 4) Teknik pembagian dan penjelasan materi jelas dan mudah dipahami siswa; 5) Dalam memonitor, membimbing, serta mengarahkan anak menemukan konsep yang diinginkan sudah baik; 6) Dalam penyimpulan materi sudah baik sehingga siswa bisa lebih faham dengan materi yang dibahas selama berkelompok; 7) Pemberian evaluasi setelah pembelajaran baik; 8) Menananggapi jawaban siswa sudah baik; 9) Baik dalam memberikan penghargaan kepada kelompok terbaik; 10) Rata-rata persentase perolehan skor aktivitas siswa dalam PBM 84,17\%; 
dan 11) Rata - rata persentase hasil observasi aktivitas guru dalam mengajar rata-ratanya $84,09 \%$.

Adapun keberhasilan yang terjadi pada siklus ketiga adalah sebagai berikut: 1) Aktivitas siswa dalam PBM sudah mengarah kepada pendekatan pembelajaran kooperatif tipe Jigsaw. Siswa mampu membangun kerja sama dalam kelompok untuk memahami tugas yang diberikan guru, dan menyelesaikan tugas tepat waktu. Hal ini bisa diperoleh dari hasil observasi aktifitas siswa dalam pembelajaran meningkat dari $75,97 \%$ pada siklus kedua menjadi $84,17 \%$ pada siklus ketiga, 2). Meningkatnya aktivitas siswa dalam PBM didukung oleh meningkatnya aktivitas guru dalam mempertahankan dan meningkatkan suasana pembelajaran yang mengarah pada pembelajaran kooperatif tipe Jigsaw. Hasil observasi aktivitas guru meningkat dari $72,73 \%$ pada siklus kedua menjadi $84,09 \%$ pada siklus ketiga, dan 3). Meningkatnya persentase ketuntasan ulangan harian dari $80,56 \%$ pada siklus 2 menjadi $97,22 \%$ pada siklus 3 .

Berdasarkan data-data di atas dapat diambil suatu kesimpulan bahwa dalam materi menghitung luas permukaan bangun ruang sisi datar yang meliputi kubus, balok, prisma, dan limas terjadi peningkatan karena 1) Aktifitas siswa dalam pembelajaran mencapai lebih dari 75\%, dan 2) Tingkat ketuntasan ulangan harian siswa sudah mencapai $97,22 \%$ dari jumlah siswa sedangkan standar ketuntasan yang telah ditentukan $85 \%$ dengan nilai minimal sama dengan KKM yaitu 70. Dengan hasil yang diperoleh seperti ini, pada siklus 3 ini sudah dikatakan baik dan sesuai dengan harapan peneliti. Penelitian tindakan kelas siklus 3 ini bisa juga diasumsikan tidak ada masalah yang signifikan terhadap pembelajaran materi menghitung luas permukaan kubus, balok, prisma, dan limas dengan menggunakan model Jigsaw pada siswa kelas $\mathrm{X}$ sehingga penelitian dihentikan.

\section{Pembahasan Penelitian}

PTK ini dilaksanakan dalam tiga siklus. Pada siklus yang ketiga, PTK ini telah mampu memenuhi target dan harapan peneliti. Paparan hasil penelitian secara keseluruhan dapat dilihat pada Tabel 1 dibawah ini.

Tabel 1.Hasil Penelitian Pada Siklus ke-1 sampai dengan Siklus ke-3

\begin{tabular}{clccc}
\hline \multirow{2}{*}{ No. } & \multicolumn{1}{c}{ Hasil Kegiatan } & $\begin{array}{c}\text { Siklus } \\
\text { Ke-1 }\end{array}$ & $\begin{array}{c}\text { Siklus } \\
\text { Ke-2 }\end{array}$ & $\begin{array}{c}\text { Siklus } \\
\text { Ke-3 }\end{array}$ \\
\hline 1. & Prosentase aktivitas siswa dalam & $63,47 \%$ & $75,97 \%$ & $84,17 \%$ \\
2. & PBM & $63,64 \%$ & $72,73 \%$ & $84,09 \%$ \\
3. & Respontase aktivitas guru & $86 \%$ & 86,52 & $88,14 \%$
\end{tabular}




\begin{tabular}{llrrc} 
4. Rata - rata tes setelah pembelajaran & 52,64 & 68,47 & 91,57 \\
5. Rata - rata ulangan harian & 57,36 & 83,63 & 89,87 \\
6. Prosentase siswa yang tuntas & $36,11 \%$ & $80,56 \%$ & $97,22 \%$ \\
\hline
\end{tabular}

Peningkatan ini sejalan dengan pendapat Sanjaya (2007 : 138) bahwa pembelajaran yang berpusat pada peserta didik adalah salah satu bentuk inovasi dalam memperbaiki kualitas proses belajar mengajar bertujuan untuk membantu peserta didik agar bisa belajar mandiri dan kreatif sehingga ia dapat memperoleh pengetahuan, keterampilan, dan sikap yang dapat menunjang terbentuknya kepribadian yang mandiri. Pendapat ini diperkuat oleh Ibrahim M., dkk (2000 : 7-8) yang menyatakan bahwa pembelajaran kooperatif dapat meningkatkan penilaian siswa pada belajar akademik dan perubahan norma yang berhubungan dengan hasil belajar. Selain mengubah norma yang berhubungan dengan hasil belajar, pembelajaran kooperatif dapat memberi keuntungan baik pada siswa kelompok bawah maupun kelompok atas yang bekerja sama menyelesaikan tugas-tugas akademik. Siswa kelompok atas akan menjadi tutor bagi siswa kelompok bawah, jadi memperoleh bantuan khusus dari teman sebaya, yang memiliki orientasi dan bahasa yang sama.

Berdasarkan hasil penelitian ini, maka PTK ini mengarah pada hipotesis penelitian yang telah ditetapkan dengan model Jigsaw dapat meningkatkan pembelajaran materi menghitung luas permukaan bangun ruang sisi datar yang meliputi kubus, balok, prisma, dan limas.

\section{KESIMPULAN DAN SARAN}

\section{Kesimpulan}

Berdasarkan temuan hasil PTK dapat disimpulkan bahwa penggunaan model Jigsaw dapat meningkatkan pembelajaran Matematika pada materi menghitung luas permukaan bangun ruang sisi datar, seperti kubus, balok, prisma, dan limas. Hasil observasi aktivitas siswa dalam pembelajaran, aktivitas guru dalam menerapkan model Jigsaw, hasil kegiatan tes setelah pembelajaran, dan hasil kegiatan ulangan harian menunjukkan adanya peningkatan mulai dari siklus pertama sampai dengan siklus ketiga. Hal ini menunjukkan bahwa penggunaan model Jigsaw dalam pembelajaran Matematika berjalan efektif dan efisien, serta lebih menyenangkan karena siswa terlibat aktif dalam pembelajaran.

\section{Saran}

Saran yang perlu disampaikan dari PTK ini adalah pentingnya penggunaan model Jigsaw yang bersifat saling membantu atau bekerja sama 
antar sesama siswa sehingga pembelajaran Matematika dapat berjalan efektif, dan pemberian penghargaan secara kelompok sehingga siswa termotivasi untuk belajar. 


\section{DAFTAR RUJUKAN}

Adinawan, M. C., dkk. (2007). Matematika untuk SMP Kelas VIII Semester 1, Jakarta : Erlangga.

Ibrahim, M., dkk. (2000). Pembelajaran Kooperatif, Surabaya : University Press UNESA.

Kunandar. (2008). Langkah Mudah Penelitian Tindakan Kelas Sebagai Pengembangan Profesi Guru, Jakarta : Rajagrafindo Persada.

Suprijono, A. (2009). Cooperative Learning Teori dan Aplikasi PAIKEM, Yogyakarta : Pustaka Pelajar.

Sutikno, M. S. (2007) Menggagas Pembelajaran Efektif dan Bermakna, Mataram : NTP Press.

Sanjaya, W. (2006). Strategi Pembelajaran Berorientasi Standar Proses Pendidikan, Jakarta : Kencana Prenada Media Group.

Widayati, S. N. (2009). Penelitian Tindakan Kelas ( hand out), Surabaya : LPMP. 